\title{
A Collective Household Labour Supply Model with Disability: Evidence from Iraq
}

\author{
Eleftherios Giovanis ${ }^{1}\left[0 \cdot\right.$ Oznur Ozdamar $^{2}$
}

Published online: 15 October 2018

(c) The Author(s) 2018

\begin{abstract}
In this study we explored the determinants of the women's labour supply and we attempted to identify the sharing rules for married couples. The analysis relied on data derived by the Iraqi Household Socio-Economic Survey (IHSES) in 2012-2013. The study considered the housework contributed by both spouses and we also included the wife's disability status as a distribution factor. Moreover, we estimated the sharing rules accounting for female non-participation in the labour market. The household collective model was preferred over the unitary model as the results supported that changes on wages, non-labour income, age, education, number of children, and disability as a distribution factor affect the bargaining power and the share of spouses. The findings showed that for a one percent increase on female's daily wage rate, her share on full income was increased by 1320 Iraqi Dinar (ID) corresponding to $\$ 1.12$, while reached 1470 ID $(\$ 1.25)$ when the domestic labour was considered. Similarly, increases on the male's wage increased her share by 630 ID $(\$ 0.50)$, while increases of 1 ID in the non-labour income increased female's share by 0.43 . The estimates showed that the disabled women decreased the share by 1275 ID (\$1.08). Furthermore, the findings illustrated that considering the non-participation of the wife in the labour market, her share and therefore her bargaining power was lower than their earner counterparts.
\end{abstract}

Keywords Collective model $\cdot$ Disability $\cdot$ Household behaviour $\cdot$ Labour supply $\cdot$ Sharing rule $\cdot$ Unitary model

\section{Introduction}

Household resource allocation and participation in the labour market have always been major topics of research in economics. Earlier research has developed various theories in an attempt to identify the patterns that the household members participate in the labour market and share the

Electronic supplementary material The online version of this article (https://doi.org/10.1007/s10834-018-9597-0) contains supplementary material, which is available to authorized users.

Eleftherios Giovanis

giovanis95@gmail.com; L.giovanis@mmu.ac.uk

Oznur Ozdamar

oznur.ozdamar@adu.edu.tr

1 Department of Economics, Business School, Policy and International Business (EPIB), Manchester Metropolitan University, All Saints Campus, Oxford Road, Manchester M15 6BH, UK

2 Department of Econometrics, Faculty of Economics, Adnan Menderes University, Kepez Mevkii, Merkez Kampüsü, 09010 Efeler, Aydın, Turkey resources maximising their utilities. The first applications rely on the unitary model that treats the household as an individual who maximises her utility. The household is considered as one entity which interacts only with the outside world economy and society.

Chiappori (1988) proposed a household collective model, where it is assumed that each household member is characterized by his (her) own utility function and that decisions result in Pareto-efficient outcomes. This specification rules out various forms of altruism in which each individual cares about the other's utility and consumption of private goods, and the advantaged member can have preference that favour redistribution. Overall, there is no agreement at present on which model is appropriate and indeed it may be that different models are relevant in different contexts (Browning et al. 2006).

This study aims to answer how the spouses determine the household choices of labour supply and resource allocation, based on individual and household characteristics and disability of women as a distribution factor. Disability is a topic of major interest, especially in the case of Iraq, where people have been disproportionally affected by 
violence, terrorism, and armed conflicts that were dominating the country over several decades and have prevailed since 2003 following the Iraqi war. While those disabled persons belong to various kinds of religious communities and ethnic groups, and in all gender and age groups, they face common experiences of often multiple and aggravated forms of discrimination that deteriorate their well-being and hinder their right to participation in all aspects of the society (Makkonen 2002; Warner and Brown 2011).

It is very important to recognise that the provision of care for a disabled family member may compete with other activities, such as productive employment and schooling, exacerbating existing differentials in resource allocation (Pitt and Rosenzweig 1990). Therefore, especially due to poverty conditions, disabled people's problems are often only met when other household members' needs are acquired (Burchardt and Zaidi 2008; Cullinan and Lyons 2015; Ozdamar and Giovanis 2016; Pitt and Rosenzweig 1990; Tibble 2005).

The motivation of the study lies on the fact that women's labour supply, especially in the Middle East and North Africa (MENA) countries, is very low and the health conditions and disability status may even have a stronger adverse impact on household resource allocation. Even though the women's labour supply-participation has increased substantially in the last 50 years, and especially in the developed countries, there are still time allocations to both household work and market that are highly differentiated by gender (Bianchi et al. 2014; Cooke and Janeen 2010; Sayer et al. 2004). Iraq is one special case, where the men still dominate in the labour market in terms of wage and professional class (United Nations 2015).

The analysis about the ways that the domestic and household labour is shared within the household is essential for social and economic policy evaluation, especially in the Iraqi context, where we consider also the disability status of women. Additionally, we will explore the non-participation of wife in the labour market and this can be crucial about the effect of changes in the potential wage of non-participating members, providing key insights into the bargaining process. To the best of our knowledge there is no study so far in Iraq, investigating the relationship between gender, disability, and access to labour market, as the majority of the literature review examines US, British, and other European cases.

This paper is structured as follows: Second section presents an overview of the previous literature and approaches to labour supply modelling. Third section describes in details the theoretical framework and the setup of the empirical model. The next section describes the dataset used in the empirical work, while in the Empirical Results section we report the main findings and limitations of our analysis. Finally, in the last section, we discuss the concluding remarks of the study.

\section{Literature Review}

Becker (1981) was probably the first that formalized the household behaviour within the extension of the neoclassical consumer demand models to families. Nevertheless, Samuelson (1956) before Becker already developed the household welfare function to express social indifference curves. Therefore, considering and combining the frameworks by Samuelson and Becker, we assume that the household attempts to maximise a joint welfare function where the marginal rate of substitution is equal across all the pairs of goods. The unitary model treats the household to behave in the same way as the individual does, implying that the neoclassical consumer theory axioms and assumptions can be applied (Vermeulen 2002). However, neoclassical consumer theory applies only to individuals and not to groups. Moreover, according to the Arrow's Impossibility Theorem, group preference relations do not necessarily behave in the same way as those for the individuals and therefore they cannot be modelled in the same fashion (Browning and Chiappori 1998).

One of the testable restrictions of the unitary model is the income pooling, which is a condition where the household resources, including the non-labour income, labour, capital, and land are pooled together. Earlier literature used collective models to examine the consumption allocation and to test the income pooling which was rejected in the majority of the studies (Attanasio and Lechene 2002; Arias et al. 2004; Blundell at al. 2005, 2007; Bourguignon et al. 1993; Chavas et al. 2018; Chiappori 1988, 1992; Chiappori et al. 2002; Fortin and Lacroix 1997; Giovanis and Ozdamar 2018; Lundberg et al. 1997).

In another study by Hendy and Sofer (2010), the intrahousehold resource allocation in the married couples in Egypt and the plausible impact on the female labour supply was explored. The authors employed data from the Egyptian Labor Market and Panel Survey of 2006 and they tested new innovative distribution factors, such as the female's contribution to the total cost of the marriage (Roushdy 2004) and the "moakhar," which represents the amount of the money that the husband must pay to his wife in the case of divorce. The results showed that females' contribution to marriage costs influenced significantly their labour supply choices. Moreover, the authors suggested that females tend to spend their own money on the household as the estimated share was negative, but the sharing rule parameters were statistically nonsignificant.

Following the methodology by Chiappori (1992) and Rapoport et al. (2011), we considered wife's disability status as a distribution factor, instead of the sex ratio or relative wages and income. In particular, any exogenous variable internal or external to the household that has no direct impact on preferences or the household budget constraint, 
but influences the household behavior, can be defined as a potential distribution factor. Therefore, shifts in distribution factors affect the intra-household decision process on the distribution of the resources and the welfare of individuals within the households, but they do not shift its utility possibility frontier. In other words, these variables influence the family behaviour only through the effect on the intra-household decision process, but do not enter into the household's budget constraint or the individual preferences. In our case, the working supply functions may depend on such distribution factors and therefore a shift on them will have consequences for the intra-household decisions and the individuals within the household (Chavas et al. 2018; Chiappori et al. 2002; Chiappori and Ekeland 2009). Also, household composition, region, and marital status are important facto of time preferences to labour supply and leisure (Hiatt and Godwin 1990; Hilton 1990). The sex ratio has been employed by earlier studies as a distribution factor and is defined as the number of men divided by the number of women of specific age groups or the whole population. This is also used as a proxy to the marriage market restriction and is likely to influence the female labour force participation and propensity of divorce (Chiappori 1992). Thus, a negative sign will imply a higher number of men and reduced number of working hours for women or lower probability of female participation in the labour market.

One issue is how convincible can be the disability to serve as a potential distribution factor. Our argument lies on the fact that as in the case of education differences between household members used as a distribution factor, it does not affect directly the preferences, but influences the household allocation decisions. Thus, we claim that disability is an exogenous variable, especially in the case of war and armed conflicts. Overall, one of the main elements of the distribution factor independence hypothesis (DFI) and which has received a lot of attention in the literature is to test the unitary model by the income pooling condition. One possible objection to the use of a distribution factor based on the individual's disability status level is that does not enter preferences, whereas disability can be a preference factor. In this study we consider the hours spent in the household-domestic production. So, non-disabled wives with lower disability levels will spend more hours in the labour market and household chores than their disabled counterparts. This implies a higher relative bargaining and decision power for the wife allowing her to claim a larger share of the non-labour income (Browning et al. 2006; Crespo 2009). In a study by Butikofer et al. (2011) the findings suggested that the older wives consumed between 30 and $42 \%$ of total household expenditures, however, these shares increased dramatically when the husband's health was poorer. Nevertheless, in this study we explored the resource allocation considering the wife's disability and compared the household resource allocations between the disabled and non-disabled wives.

So far the choice of the variables entering the Pareto weight is mostly based on an informal justification for the inclusion of one or another variable. However, the aim of the study is not to test the collective versus the unitary model, as the previous studies show that the sharing rule always depends on labour supply and total expenditure through the budget constraint and the Pareto weight. Also, if the sharing rule depends on the distribution factors, it does not imply a preference of the one model over the other, but it only indicates whether demand depends on distribution factors. From the point of view of policy, previous studies used the income share, considering it is an important distribution factor, because relevant policies and reforms may alter or affect this variable. Therefore, following this logic, our aim is to examine the female disability status. Recovering the sharing rules based on this factor, relevant policies including disability benefits and integration in labour market and other social aspects of life for women can be implemented. In this case we can conceive a model where resources are pooled, but allocation of expenditures and thus the sharing rule depend also on other distribution factors besides income. So far we concluded that the choice of variables entering Pareto weight, the structure of the model and whether this is unitary or collective and the justification of the distribution factor depends on different contexts. Since disability is a common characteristic of the Iraqi society, we chose the female disability as a distribution factor which is useful to recover the sharing rules and investigate some features of the intra-household decision process on labour supply. Furthermore, even though the disability can also affect preferences, our main aim in this study is to recover the sharing rules and to compare them between disabled wives and their nondisabled counterparts.

Overall, the main motivation and contribution of this study is threefold. First, the aim was to identify conditions of a more general class of household production functions, without pooling together leisure and household domestic production. Thus, we recognize that the allocation of time between working in the labour market, time spent on household work, or production, and leisure may vary. In particular, we found that the presence of young children reduces the labour supply of women and increases the household production time, which includes cooking, cleaning, and child care. However, earlier literature assumes that the household labour time is entirely leisure (Chiappori 1988, 1992; Chiappori et al. 2002; Fortin and Lacroix 1997). Failure to distinguish between leisure and household labour supply will most probably lead to measurement errors in terms of the sharing rule. The intensive household labour time may explain the relationship between low female labour market supply and a larger share of the household full income, as the 
household production is being traded for monetary income with little leisure. Thus, this real leisure time differs between men and women and this may explain possible measurement errors of the bargaining power through the sharing rule.

Very few papers have attempted to analyse the household production within a theoretical framework and empirical analysis (Aronsson et al. 2001; Rapoport et al. 2011). This is important because the household production accounts for more than $50 \%$ of the labour market activity and more specifically, it constitutes from 60 to $80 \%$ of the total working time for women and 30-40\% for men (Goldschmidt-Clermont and Pagnossin-Aligisakis 1995). Therefore, an important drawback in the earlier studies is that the estimation of the sharing rule depends on an unclear definition of leisure where in the majority of the case studies, household labour time is defined as leisure.

Second, the aim was to extend the model by Rapoport et al. (2011) considering and identifying also men's housework function. This is important because given the household composition, wages, education, and age, the household labour time of men may significantly differ. In particular, we found that husbands with very young children increased their household labour time, while those with older children were more likely to spend more time in the labour market. Furthermore, including the housework labour time, the sharing rule may considerably increase, especially in the case of wives. Thus, pooling together the household labour time with leisure may lead to biased estimates of the sharing rule.

Third, we included the female non-participation in the labour market and their disability status as a distribution factor, given the gender gap in terms of employment, wages, and other social aspects. The motivation of exploring the wife's disability status lies on the fact that women, especially with psycho-social disabilities, are at particular risk of exploitation, sexual harassment, and abuse (USAID 2014). According to a report of United Nations (UN), a double discrimination against women with disabilities is reported which is linked to their special living condition (United Nations 2016). In particular, the double discrimination refers to the women's imprisonment by both disability and society norms, beliefs, and traditions about their participation in the labour market and the gender role attitudes. These reports reveal that disabled men are still generally more likely to have more educational opportunities and obtain better jobs compared to women with disabilities.

Disabled women are further burdened by lack of freedom resulting from gender, societal and traditional beliefs-values, and expectations, and thus face more difficulties accessing basic services, completing education and finding employment. Additionally, disabled women are far less aware about their rights and how to claim them. Indeed, earlier studies found that women with disabilities have a particular disadvantage in relation to their access to education, which is derived by the society's perception that women's education is not valued and is not considered to be a priority (UNICEF 2010). Thus, the main motivation of the study is that we aim to explore the impact of disability status of women, since they are limited by both societal norms and their living conditions. However, earlier studies mainly explored the western countries, while the interest in the Iraqi case is mainly limited. The study by Jones et al. (2006) showed that both disabled and non-disabled men in UK earned more than even non-disabled women on average. This is expected to be also the case in the Iraqi society, and for this reason we also include the female non-participation in the labour market to highlight the discrepancies.

\section{Conceptual Framework and Research Methodology}

One of the major causes of disability in MENA (Middle East and North Africa) region is the conflicts, including examples from Algeria, Iraq, and West Bank and Gaza. In addition to the direct effect of violence, contending demands on scarce human and financial resources nations result in decreasing prevention mechanisms, which lead to conditions that exacerbate disabilities. Iraq has also suffered the consequences of three major wars, resulting in the poorest health outcomes in the region. As a result, the prevalence of physical disabilities and chronic mental problems among the working age population in Iraq has increased dramatically. Previous studies show that people with disabilities, experience worse educational and labour market outcomes and are more likely to be poor than the non-disabled persons (Parodi and Sciulli 2008; Zaidi and Burchardt 2005). A study by OECD (2009) covering 21 upper-middle and high-income countries shows higher poverty rates among working-age people with disabilities than among working-age people without disability in all but three countries: Norway, Slovakia, and Sweden.

Another important fact is that none of the countries has yet introduced specific legislation or enforced rules that prohibit discrimination on the basis of disability. There are two main models aim to reduce inequalities in the labour market. The first relies on anti-discrimination legislation and laws, including monitoring, and the concept of corporate social responsibility to encourage equality in the employers' recruitment and hiring processes.

The second relies on the hiring quotas imposed by the government accompanied with the possibility of severe penalties in cases of breaching. Nevertheless, the majority of these countries have not implemented these regulations and even they have been signed or passed, these are not applied in reality. From 20 MENA, countries 13 have not signed the Optional Protocol to the Convention of the Rights of Persons with Disabilities (CRPD) including Iraq. This defines 
as "persons with disabilities those with long-term physical, mental, and intellectual impairments which in interaction with various barriers may hinder their full and effective participation in society on an equal basis with others" (United Nations 2007, p. 4). This Protocol allows people with disabilities to bring complaints to the Committee on the Rights of People with Disabilities in cases where their rights have been violated. Additional CRPD protocols have been also ignored in MENA countries.

The lack of anti-discrimination legislation in these countries that could reinforce obligations to accommodate persons with disabilities, for example in the labour market, is another reason for the weak effectiveness of the quota systems and disability benefits in place (Rioux and Pinto 2014). The evidence provided by earlier studies shows that the intra-household collective framework is proper as it predicts that disabled wives will spend less time on labour market than their non-disabled counterparts (Gallipoli and Turner 2009). Moreover, studies show that the intra-household model on allocation time and labour supply choices is relevant for policy makers, because the household labour supply and demand both depend on who in the household is subsidied or taxed. Thus, the motivation of this study is to explore the resource household allocation considering female disability as a distribution factor, and since many policies and reforms are missing from these countries, relevant implementation and government intervention can alter the disability variable and the sharing rule.

The model used in the empirical work relied on the assumption that the household decisions are Pareto-efficient (Apps and Rees 1988; Bourguignon et al. 2009; Browning et al. 1994; Chiappori 1988, 1992). In addition, we included age and education level as individual characteristics and the female disability as a distribution factor. We assumed that the spouses had individual preferences over the consumption of an aggregate market good $c$, leisure time $l$ and a domesticproduced good $q$, which included cooking, cleaning, childcare, and others. The production function for the domestic good-chore $q$, using the working hours by female and male denoted respectively by $t_{f}$ and $t_{m}$ was:

$q=f\left(t_{f}, t_{m}\right)$

The household maximised the following weighted utilitarian household welfare function:

$\max _{l_{f}, l_{m}, C_{f}, C_{m}, q_{f}, q_{m}} \mu\left[U_{f}\left(l_{f}, C_{f}, q_{f} ; \mathbf{z}\right)\right]+(1-\mu)\left[U_{m}\left(l_{m}, C_{m}, q_{m} ; \mathbf{z}\right)\right]$

$\mathbf{z}$ was a vector of individual and household characteristics, including age, education, disability, the number of children and whether the area-location was urban or rural. The Pareto weight component $\mu$ represented the importance of the couple in the intra-household collective decision process. Under the collective setting $\mu$ was a function that captured the bargaining power of individuals contained in $[0,1]$ and it was continuously differentiable in all its arguments and variables that affected each member's bargaining power expressed as $\mu=\mu\left(w_{f}, w_{m}, y, s_{1}, \ldots ., s_{R}\right)$. Therefore, $\mu$ was a function of wages, non-labour income and the vector $\mathbf{s}$ that included the distribution factors. The maximisation function (2) was subject to the following constraints:

$$
\sum_{i=f, m} C_{i}=\sum_{i=f, m} L_{i} w_{i}+y+p_{q} q-\sum_{i=f, m} w_{i} t_{i}
$$

$T_{i}=h_{i}+L_{i}$

Relation (3) was the budget constraint, $w$ was the wage for $i=m, f$ indicating male and female respectively, $C$ was the consumption and $y$ was the household non-labour income, including assets, transfers and savings. The term $p_{q} q-\sum_{i=f, m} w_{i} t_{i}$ was the profit function, $t_{f}$ and $t_{m}$ were the hours devoted to the household production for female and male respectively. The term $w_{i} t_{i}$ represented the cost of the household chore-production, which was expressed as the opportunity cost or time loss that could have been used in the labour market.

In the time constraint (4) we defined $h_{i}=t_{i}+l_{i}$, where $t_{i}$ was the time use on household domestic production, $l_{i}$ indicated the leisure, and the labour supply was represented by $L_{i}$ and consequently the total time was denoted by $T$. The vector $\mathbf{s}$ only appeared in the Pareto weight, affecting the bargaining power or position of the adult members, but not their preferences or the household budget constraint (Donni and Moreau 2007; Bourguignon et al. 2009). More details and information about the solution of the model can be made upon request. Following Chiappori et al. (2002) and other studies (Donni and Moreau 2007; Bourguignon et al. 2009; Rapoport et al. 2011) we used a semi-logarithmic specification, for the female and male labour supply equations as:

$h l^{f}=a_{0}+a_{1} \ln w_{f}+a_{2} \ln w_{m}+a_{3} \ln w_{f} \ln w_{m}+a_{4} y+a_{5} s+a^{\prime} \mathbf{z}$

$h l^{m}=b_{0}+b_{1} \ln w_{f}+b_{2} \ln w_{m}+b_{3} \ln w_{f} \ln w_{m}+b_{4} y+b_{5} s+b^{\prime} \mathbf{z}$

In the structural system (5) and (6) the $h l$ denoted the working hours per day for male and female represented by $m$ and $f$ respectively, $w, y$ and $s$ denoted respectively the wage, non-labour income and the distributional factors, while $\mathbf{z}$ was defined as in (2). To estimate and test a collective model of labour supply we must specify the proper function form for the individual labour supply functions. The parameterisation of the semi-logarithmic system (5) 
and (6) is convenient as it satisfies a number of desirable properties. First, in its unrestricted form it does not a priori impose all the restrictions of the model and therefore, allows them to be tested. Also, the collective restrictions of the model do not impose unrealistic constraints under this functional form and it becomes easier to recover the sharing rule. Another important advantage of the logarithmic form is that wage rates reflect a more realistic behaviour than the linear terms as it allows the effect of the wage on the labour supply to decrease with the hours of work, which is the case that labour supply is upward sloping.

However, one limitation of the semi-logarithmic specification is that some restrictions of the unitary model consistent with this system may impose unrealistic labour supply behaviour and others do not, and thus, these cannot be tested. Nevertheless, we rely on previous studies, discussed in the earlier parts, where the majority has rejected the unitary model and have used the semi-logarithmic form. From the relations (5) and (6) we computed the derivatives of the sharing rules (7) and (8) and details can be provided upon request.

$\varphi_{f}=\frac{B C}{D-C}-t_{f}=\frac{a_{5}\left(b_{1}+b_{3} \ln w_{m}\right)}{\Delta w_{f}}-t_{f}$

$\varphi_{m}=\frac{A D}{D-C}-t_{m}=\frac{b_{5}\left(a_{2}+a_{3} \ln w_{f}\right)}{\Delta w_{m}}-t_{m}$

Thus, the extension of the model explored in this study was the new components that entered (7) and (8) defined by the $t_{f}$ and $t_{m}$ which was the time used respectively by the wife and husband to household chores and it was fully observed in our case. Therefore, we extended the model by Rapoport et al. (2011), including also the husband's contribution to housework. Since we had a simultaneous system (5) and (6), the seemingly unrelated, three stage least squares (3SLS) and Generalised Methods of Moments (GMM) can be applied. GMM was preferred to 3SLS as it provides efficient estimates of the parameters, accounting for the possible correlation between the error terms in the male and female labour supply equations. Also, GMM computes efficient estimators even when the errors are heteroskedastic of an unknown form (Davidson and MacKinnon 1993). In summary, we first estimated the labour supply functions and after taking their estimated coefficients we estimated the sharing rule of the model proposed by Chiappori et al. (2002) with non-market time treated as "pure" leisure. Then we re-estimated both sets of parameters, but we took into account the time contributed in the household-domestic production.

So far the analysis relied on the fact that both spouses participate in the labour market. We extended the econometric analysis accounting also for spouses' labour market non-participation. The index for labour market participation was:

$l p_{i}^{j}=a_{0}+a_{1} w_{i}^{f}+a_{2} y_{i}+a^{\prime} \mathbf{z}+u_{i}^{j}$

Variables $w$ and $y$ are defined as previously, for male $m$ and female $f$ in household $i$, while $l p$ denoted the labour market participation decision for $j=m, f$. However, in our case we limited the sample to husbands that always participated in the labour market, while we considered for female also the possibility of non-participation. We also allowed for a flexible function form inserting quadratic terms on age. We assumed that wages do not depend on the characteristics of the spouse and the wage equations taking a standard approach of human capital were:

$$
\begin{aligned}
& w_{i}^{f}=b_{0}+b_{1} a g e_{i}^{f}+b_{2}\left(a g e_{i}^{f}\right)^{2}+b_{3} e d u c_{i}^{f}+b_{4} D_{i}^{f}+b^{\prime} \mathbf{z}+u_{i}^{f} \\
& w_{i}^{m}=b_{0}+b_{1} a g e_{i}^{m}+b_{2}\left(a g e_{i}^{m}\right)^{2}+b_{3} e d u c_{i}^{m}+b_{4} D_{i}^{m}+b^{\prime} \mathbf{z}+u_{i}^{m}
\end{aligned}
$$

$D$ denotes whether the respondent was disabled, as it may determine the wage depending on the disability and severity status, and vector $\mathbf{z}$ was defined as before. We implemented the two-step Heckman selection model (Heckman 1979) to predict the wages, corrected for sample selection and considering also wives that did not participate in the market. Since we considered only the female participation, the wage Eq. (10) included the age, education level and disability status of wives, while additional controls in vector $\mathbf{z}$ included the number of children and the urban area. The participation equation included the wife's wage rates and the household non-labour income as we have seen in (9), and the additional factors in vector $\mathbf{z}$, as age, spouses' education, the number of children, and the urban area. The instruments excluded from the participation equation refer to the respondent's employment sector, such as whether is public, private, or self-employed; the geographical area, which indicates city, town, or village; the Gadah-district and the second order polynomial term of age.

The key problem observed in the wage and participation equations is that we observe the characteristics in the regression of wages for those who are employed, but we are unable to observe the equation for the whole population. Hence, the results will tend to be biased, due to possible sample selection bias and the size of the bias would be mainly driven by the correlation between the errors in the two models; the wage and participation equation. 


\section{Data}

The analysis in this study relied on data derived from the Iraq Household Socio-Economic Survey (IHSES) over the period 2012-2013. IHSES is a household survey programme which aims to produce high quality data and improved survey methods. It was developed by the need to improve the statistical data at the household level which are required for design, analysis, implementation and evaluation of the social policies in developing countries. Additionally, the aim of the IHSES programme is to offer a measurement and understanding of the living conditions, the interaction of government spending and programmes along with the household behaviour and the assessment of these policies. The regression analysis was based on weights by the inverse of measurement error variance. In particular, the inverse variance weighting is a method that aggregates two or more random variables to minimise the variance of the weighted average. In our case, the weight was the inverse of the selection probability, adjusted to match the Gadah -district population, while our cluster was based on that district.

In Table 1 we present the $t$-statistics hypothesis tests of equality between the couples of the main variables used in the empirical work. These statistics refer to two-earner

Table 1 Summary statistics and t-statistics for married two-earner couples in Iraq

\begin{tabular}{|c|c|c|c|c|}
\hline Variables & Males & Females & T-statistic & p-value \\
\hline \multicolumn{5}{|l|}{ Panel A: spouses characteristics } \\
\hline Wage (in 1000 ID) & $31.119(5.430)$ & $27.870(2.891)$ & 2.409 & 0.0092 \\
\hline Age & $38.094(0.5542)$ & $30.322(1.044)$ & 7.183 & 0.0000 \\
\hline \multicolumn{5}{|l|}{ Education } \\
\hline No-certificate-illiterate & $0.0477(0.0129)$ & $0.0183(0.0081)$ & 2.328 & 0.0206 \\
\hline Elementary school & $0.1764(0.0231)$ & $0.0772(0.0162)$ & 3.959 & 0.0001 \\
\hline High school & $0.1801(0.0233)$ & $0.1617(0.0223)$ & 0.554 & 0.5795 \\
\hline University degree & $0.5625(0.0301)$ & $0.7242(0.0271)$ & -4.462 & 0.0000 \\
\hline Postgraduate and higher education & $0.0183(0.0081)$ & $0.0330(0.0108)$ & -1.069 & 0.2859 \\
\hline Time use on household chores & $0.5989(0.0641)$ & $3.943(0.1366)$ & -20.646 & 0.0000 \\
\hline Time use on caring of children and elderly & $0.7618(0.1247)$ & $2.4247(0.1987)$ & -7.334 & 0.0000 \\
\hline Time use on labour market & $5.3386(0.2669)$ & $3.7690(0.2536)$ & 5.625 & 0.0000 \\
\hline Time use on leisure & $2.9008(0.1731)$ & $2.5371(0.1482)$ & 3.050 & 0.0025 \\
\hline Variables & Disabled & Non-disabled & T-statistic & p-value \\
\hline \multicolumn{5}{|l|}{ Panel B: disabled characteristics } \\
\hline Wage (in 1000 ID) & $19.409(1.028)$ & $26.016(1.352)$ & -2.174 & 0.0253 \\
\hline Age & $39.404(1.218)$ & $35.882(0.2385)$ & 3.156 & 0.0016 \\
\hline \multicolumn{5}{|l|}{ Education } \\
\hline No-certificate-illiterate & $0.4252(0.0533)$ & $0.3096(0.0108)$ & 2.268 & 0.0234 \\
\hline Elementary school & $0.3563(0.0516)$ & $0.3396(0.0111)$ & 0.321 & 0.7482 \\
\hline High school & $0.1379(0.0371)$ & $0.1745(0.0089)$ & -0.881 & 0.3783 \\
\hline University degree & $0.0689(0.0273)$ & $0.1700(0.0088)$ & -2.482 & 0.0132 \\
\hline Postgraduate and higher education & $0.0060(0.0018)$ & $0.0214(0.0091)$ & -2.322 & 0.0213 \\
\hline Time use on household chores & $0.2432(0.0880)$ & $1.4795(0.0432)$ & -2.260 & 0.0207 \\
\hline Time use on caring of children and elderly & $0.2972(0.1086)$ & $1.3122(0.0319)$ & -2.419 & 0.0156 \\
\hline Time use on labour market & $4.1891(0.4797)$ & $6.7244(0.1133)$ & -2.057 & 0.0374 \\
\hline Time use on leisure & $2.8686(0.3154)$ & $1.4776(0.0549)$ & 2.411 & 0.0150 \\
\hline \multicolumn{5}{|l|}{ Panel C: household characteristics } \\
\hline Non-labour income & 2870.722 & $12,146.76$ & 0 & 190,100 \\
\hline Number of children $0-5$ years old & 0.4530 & 0.6860 & 0 & 2 \\
\hline Number of children $6-15$ years old & 1.121 & 0.9223 & 0 & 3 \\
\hline Urban area & 0.4398 & 0.4157 & 0 & 1 \\
\hline Total observations & 906 & & & \\
\hline
\end{tabular}

Standard deviation within the brackets, ID denotes Iraqi Dinars, wage rates are expressed on daily basis. Time use on labour market, leisure, household chores, caring of children and elderly are expressed on hours per day 
married couples, following the methodological framework described, while in Table 2 we reported the same statistics considering also the female non-participation in the labour market. Based on the data presented in Panel A of Table 1, we rejected the null hypothesis of equality between the spouses' characteristics, except for the educational level and in particular the proportion of couples that have completed the high school. As it was expected husbands were older, earned more, and spent less time on household chores and caring of children and elderly than their spouses. On the other hand, husbands spent more time on the labour market and leisure. Also, we reported the summary statistics for the disabled and non-disabled, for both sexes, and we found significant differences regarding wage, age, and education attainment. In particular, disabled people earn less, are older, and more likely to be illiterate than their non-disabled counterparts. Non-disabled couples are more educated, and they spend more hours on labour market, household chores, and caring of children and elderly, while we found that they spend less hours on leisure compared to disabled family members. This can be explained by the fact that healthy people devote more time on labour market and caring, especially when a disabled member is present in the household. It is very important for the disabled people to allocate more time to leisure that includes also rehabilitation activities and home care.
In Table 2 we found similar concluding remarks, but the time use of wives in household chores and childcare was significantly higher compared to the findings in Table 1. Moreover, we illustrated that husbands participate in the labour market at $7 \mathrm{~h}$ per day on average, while wives' participation was only 0.55 . This was expected, since in Table 2 we considered also the wives who did not participate in the labour market and this explained also the very low wage. A remarkable finding was that husbands spent on average more time on leisure when the wives work, while the inverse situation was observed when we considered the female non-participation in the labour market. Also, we observed that men have completed a higher education degree in higher proportions compared to women, while women presented higher proportions of low educational qualifications attainment. This gives a first impression of the household behaviour in Iraq, where women spend significantly a higher portion of their daily time on household chores and caring for other family members and much less time on labour market than their husbands. We should mention that in 2007 the female labour market participation was only $18 \%$, while males' participate rate was $81 \%$ and reduced at $14 \%$ in 2011 (United Nations 2015). Our data show that in 2012 only $21 \%$ of the women are working or actively seeking for job, while the respective percentage for men reaches $82.8 \%$. However, this percentage refers to women of any kind of marital status, including married, single, divorced, and widows. When we consider
Table 2 Summary statistics and t-statistics for married couples with non-female participation in Iraq

\begin{tabular}{lllll}
\hline Variables & Males & Females & T-statistic & p-value \\
\hline Panel A: spouses characteristics & & & & \\
Wage (in 1000 ID) & $28.752(1.347)$ & $4.159(0.3701)$ & 21.018 & 0.0000 \\
Age & $35.336(0.2557)$ & $30.819(0.2266)$ & 5.056 & 0.0000 \\
Education & & & \\
No-certificate-illiterate & $0.2365(0.0098)$ & $0.3455(0.0109)$ & -8.947 & 0.0000 \\
Elementary school & $0.3147(0.0107)$ & $0.3157(0.0108)$ & -0.078 & 0.9378 \\
High school & $0.1903(0.0090)$ & $0.1541(0.0083)$ & 3.072 & 0.0022 \\
University degree & $0.2440(0.0099)$ & $0.1780(0.0088)$ & 6.230 & 0.0000 \\
Postgraduate and higher education & $0.0143(0.0027)$ & $0.0063(0.0018)$ & 2.615 & 0.0090 \\
Time use on household chores & $0.2765(0.0178)$ & $4.0625(0.0436)$ & -79.042 & 0.0000 \\
Time use on caring of children and elderly & $0.5286(0.0282)$ & $2.2488(0.0627)$ & -7.334 & 0.0000 \\
Time use on labour market & $6.8977(0.0984)$ & $0.5397(0.0558)$ & 54.679 & 0.0000 \\
Time use on leisure & $1.5840(0.0512)$ & $1.7839(0.0543)$ & -6.887 & 0.0000 \\
Panel B: household characteristics & & & & \\
Non-labour income & 3038.527 & $11,968.472$ & 0 & 166,000 \\
Number of children 0-5 years old & 2.016 & 1.451 & 0 & 4 \\
Number of children 6-15 years old & 0.616 & 0.771 & 0 & 3 \\
Urban area & 0.335 & 0.452 & 0 & 1 \\
Total observations & 33,242 & & & \\
\hline
\end{tabular}

Standard deviation within the brackets, ID denotes Iraqi Dinars, wage rates are expressed on daily basis. Time use on labour market, leisure, household chores, caring of children and elderly are expressed on hours per day 
only the married women then female labour supply reached only the $2.7 \%$. Therefore, we find that it is also relevant to the policy makers' interests to explore additionally the nonparticipation of wives in the labour market.

We can derive some initial concluding remarks from the correlation matrix presented in Table 3. The first remark is that age, education, and wages are positively correlated, both between and within partners. Both spouses' education level is positively associated with the wife's time spent in the labour market. This may imply that first; more educated women are more likely to work additional hours resulting also to higher wage rates. Second, more educated husbands may allow or encourage their wives to actively participate more in the labour market. A higher wage of both partners is associated with higher time use to labour market and less time spent on household production-chores. Spouses' wage, education level, and time spent on labour market and household domestic production are lower when they are disabled. The correlation between spouses' age and disability status is negative, indicating that younger people are healthier. This is expected as both physical and mental health decline with age, at least in terms of the inability to function independently concerning the basic activities of daily living.

\section{Empirical Results}

We estimated a two-step Heckman selection model (Heckman 1979) to explore the determinants of the woman's participation in the labour market and the wages (Table 4). The wife's age and labour supply presented a non-monotonic relationship, illustrating an inverted U-shaped curve. Both partners' education level was positively related to the probability of labour participation. Thus, wives who are highly educated were more likely to have access to better information related to labour market opportunities, better skills and higher chances of being employed. Another factor we included into the estimates is the number of children and we showed that it was a significant determinant of the woman's labour participation. More specifically, the number of children aged $0-15$ years were negatively associated with the probability of the women to participate in the labour market. The last factor we included into the analysis is a dummy variable indicating whether the wife had disability. As we were expected, the coefficient sign was negative and significant.

Education level coefficients were positive and significant and their relationship with the wages was monotonic. Thus, more educated wives have access to better jobs and higher potential earnings. Disability had a significant and negative effect on wages earned by wives, while the number of children and the area coefficients were insignificant. According to the Wald Chi square statistic and its associated p-value we conclude that the estimated coefficients are jointly significant. Regarding the Likelihood ratio of independent equations, we failed to accept the null hypothesis which is $r h o=0$ indicating that the Heckman estimates were preferred given the value of the statistic and the zero p-value.

In Table 5 we presented the GMM estimates for the labour supply Eqs. (5) and (6). We should notice that based on the theoretical framework described in the previous section, our analysis relied only on the married couples and the survey we used is representative of the total population given the fact that the $14 \%$ of the women participated in the labour market in 2013, excluding the widowed, divorced, and single, since our theoretical framework assumes twoearner couples. In addition, $25 \%$ of the women participate in the labour market were actively seeking for job, but were unemployed.

We observed that husband's and wife's wage had respectively a negative and positive effect on the female's labour supply, and we showed that the wife's share was positively associated with increases in the husband's wage. The consequence of this increase was the wife's labour supply reduction, since the leisure is a normal good. The coefficient of the non-labour income was negative, indicating that wives in wealthier households were more likely to reduce their time use in the labour market.

Both spouses were more likely to reduce the labour supply when the children are younger than 6 years old. On the other hand, the effect of the number of children 6-15 years old was positive and significant on the labour supply for males. The findings are consistent with earlier studies, where the young children had a negative impact on men's labour supply, and the number of elder children had nonsignificant effect on women's hours worked in the labour market (Carlin and Flood 1997; Lundberg 2002; Wilfred et al. 2005). This can be explained also by the fact that public childcare arrangements and policies are missing in Iraq, compared to Europe where childcare subsidies may affect the labour supply (Brewer et al. 2016; Uunk et al. 2005). The age and education were significant factors and increased their participation time to labour market. This was expected as more educated people are more likely to participate in the labour market, working more hours and having higher potential earnings.

In the Columns (3) and (4) we reported the estimates when we considered additionally the time devoted to household domestic production, which included chores and child caring. The estimated coefficients were similar, but the effect of number of children 0-5 years old on the labour supply of women was lower. This may imply two concluding remarks: First, married and employed women spend more time in the labour market, and second, the husbands also contribute to child caring. About disability, the results remained the same for the female's labour supply equation, and the effect became higher at $-2.7 \mathrm{~h}$ from $-2.5 \mathrm{~h}$ we found in Column 


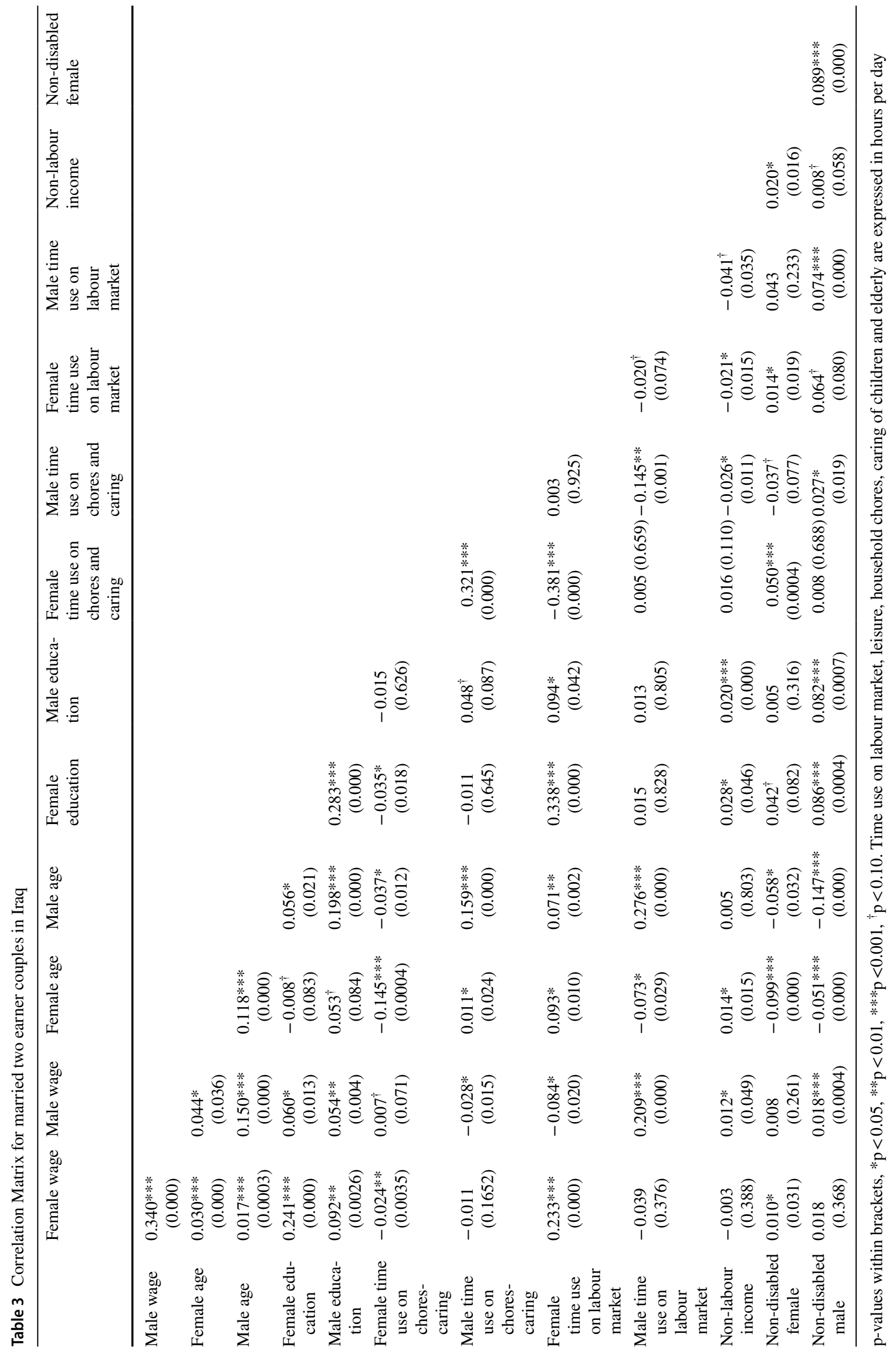


Table 4 Determinants of female labour market participation

\begin{tabular}{|c|c|c|}
\hline Variables & Participation equation coefficients & Wage equation coefficients \\
\hline Female age & $0.148 * * *(0.059)$ & $0.023 * *(0.009)$ \\
\hline Female age squared & $-0.0017 * * *(0.0002)$ & $2.4 \mathrm{e}-4^{\dagger}(1.4 \mathrm{e}-4)$ \\
\hline Male age & $0.0037^{\dagger}(0.0022)$ & \\
\hline \multicolumn{3}{|l|}{ Female education level (reference $=$ no certificate $)$} \\
\hline Female education level (primary-elementary school) & $0.329 * * *(0.098)$ & $0.2006(0.1251)$ \\
\hline Female education level (secondary school) & $0.934 * * *(0.102)$ & $0.141 * *(0.053)$ \\
\hline Female education level (university degree) & $2.287 * * *(0.103)$ & $0.391 *(0.163)$ \\
\hline Female education level (postgraduate studies and higher) & $1.732 * * *(0.294)$ & $0.905 * *(0.225)$ \\
\hline \multicolumn{3}{|l|}{ Male education level (reference $=$ no certificate $)$} \\
\hline Male education level (primary-elementary school) & $0.040(0.096)$ & \\
\hline Male education level (secondary school) & $0.092(0.101)$ & \\
\hline Male education level (university degree) & $0.279 * *(0.098)$ & \\
\hline Male education level (postgraduate studies and higher) & $0.563^{\dagger}(0.299)$ & \\
\hline Household non-labour income & $-0.026(0.021)$ & \\
\hline Number of children $0-5$ years old & $-0.081 * * *(0.0228)$ & $0.085(0.573)$ \\
\hline Number of children $6-15$ years old & $-0.141 * * *(0.0434)$ & $0.093(0.107)$ \\
\hline Female disabled & $-0.244 * *(0.092)$ & $-0.390 * *(0.159)$ \\
\hline Urban area & $-0.069(0.079)$ & $0.037(0.061)$ \\
\hline Observations & 33,242 & \\
\hline Wald Chi square statistic & $574.12[0.000]$ & \\
\hline Likelihood-ratio test & $78.08[0.000]$ & \\
\hline Likelihood-ratio test of independent equations-Rho & $52.71[0.000]$ & \\
\hline
\end{tabular}

The instrument used include the following: first the employment sector (public, private or self-employed); second the geographical area, whether living in city, town or village; third the Gadah-district and fourth a second order polynomial for age and education for wife

Standard errors within brackets, $\mathrm{p}$-values within square brackets, ${ }^{*} \mathrm{p}<0.05,{ }^{*} \mathrm{p}<0.01,{ }^{*} * \mathrm{p}<0.001,{ }^{\dagger} \mathrm{p}<0.10$

(2). Also, the coefficient of the female disability in the male's labour supply equation became significant and positive. Therefore, husbands with disabled wives were more likely to spend additional time on both labour market and household production.

As we discussed in the previous sections, the unobserved individual characteristics associated to labour supply may also be correlated with the wages and the non-labour income. For this reason, we applied the GMM method and the regressors are instrumented with variables discussed in the methodology section and that generally have been found to be correlated with both wages and non-labour income (Blundell et al. 1998; Devereux 2004; Donni and Moreau 2007; Kooreman and Kapteyn 1986; Rapoport et al. 2011). According to Hansen's J test statistic, we concluded that the excluded instruments are valid instruments and uncorrelated with the error term.

The interaction term of female disability and wage was nonsignificant in the male labour supply, and this was expected as we found that female disability had no impact, even though increases in female wage are associated with decline in the husbands' labour supply, but these are rather low. On the other hand, we observed that the coefficient was positive and significant ranging between 0.45 and 0.55 . This indicates that the labour supply declines at almost $2 \mathrm{~h}$ per day from 2.5 to $2.7 \mathrm{~h}$ when the disability was considered. The interaction of female wage and household non-labour income has no impact, except for the husbands and their total labour supply in Column (3) where the impact was found negative. This was expected as increases in wife's wage, but also to non-labour income indicates a wealthier household and gives less incentive to work additional hours.

The results also confirm the assumption that women work more hours when they have fewer or no children, while higher wages reduce the effect of children on the labour supply. Thus, it is important to control for wages, not only to derive the sharing rules, but also to identify the effect of children on wife's labour supply. Furthermore, controlling for wages we found also that more educated women who earned more are more likely to spend more hours in the labour market, while their partner spends more time on childcare and less time on labour market.

We considered the interaction terms of wage and the number of children, but we did not present the results as our main aim is to explore the sharing rules given the disability. The results showed that the higher female wage and 
Table 5 GMM estimates of the labour supply and domestic production Eqs. (5) and (6)

\begin{tabular}{|c|c|c|c|c|}
\hline \multirow[t]{2}{*}{ Variables } & \multicolumn{2}{|l|}{ Labour supply } & \multicolumn{2}{|c|}{ Labour supply and domestic production } \\
\hline & Husband & Wife & Husband & Wife \\
\hline \multicolumn{5}{|l|}{ Panel A: GMM estimates } \\
\hline Log of female wage $\ln w_{f}$ & $-0.795^{\dagger}(0.416)$ & $1.285 *(0.564)$ & $-0.502^{\dagger}(0.263)$ & $0.624^{\dagger}(0.325)$ \\
\hline Log of male wage $\ln w_{m}$ & $3.265^{*}(1.582)$ & $-3.123^{\dagger}(1.746)$ & $2.619 *(1.231)$ & $-2.816^{*}(1.224)$ \\
\hline Interaction of spouse' wages $\ln w_{m} \times \ln w_{f}$ & $0.562 *(0.255)$ & $0.538^{\dagger}(0.278)$ & $0.511^{\dagger}(0.265)$ & $0.522 *(0.229)$ \\
\hline Non-labour income $(y)$ & $-0.032 *(0.015)$ & $-0.036 * *(0.013)$ & $-0.046^{*}(0.021)$ & $-0.036^{*}(0.016)$ \\
\hline Age & $0.033 * * *(0.008)$ & $0.136 *(0.058)$ & $0.031 *(0.015)$ & $0.144 *(0.063)$ \\
\hline Education & $0.273(0.188)$ & $0.239 *(0.098)$ & $0.256(0.182)$ & $0.184(0.136)$ \\
\hline Number of children $0-5$ years old & $-0.462^{\dagger}(0.269)$ & $-0.950 *(0.468)$ & $-0.225^{\dagger}(0.121)$ & $-0.558 * *(0.216)$ \\
\hline Number of children $6-15$ years old & $0.998^{\dagger}(0.509)$ & $-0.262(0.198)$ & $1.288^{\dagger}(0.715)$ & $-0.367(0.312)$ \\
\hline Disabled female & $1.195(0.849)$ & $-2.518^{*}(1.221)$ & $1.876^{*}(0.885)$ & $-2.697 *(1.261)$ \\
\hline Disabled female $\times$ female wage & $1.375(0.927)$ & $0.463 *(0.218)$ & $1.213(1.009)$ & $0.565^{*}(0.243)$ \\
\hline Non-labour income $(y) \times$ female wage & $-0.014(0.010)$ & $-0.023(0.018)$ & $-0.031 *(0.017)$ & $-0.049(0.036)$ \\
\hline Urban area & $1.653(1.103)$ & $-1.463(1.145)$ & $-0.822(0.519)$ & $-0.918(0.671)$ \\
\hline No. observations & 906 & 906 & 906 & 906 \\
\hline \multirow[t]{2}{*}{ Hansen's J test statistic } & $6.426[0.288]$ & & $8.954[0.190]$ & \\
\hline & \multicolumn{2}{|c|}{$\partial \varphi / \partial \mathrm{x}$} & \multicolumn{2}{|r|}{$\partial \varphi / \partial \mathrm{x}$} \\
\hline \multicolumn{5}{|l|}{ Panel B: sharing rules for wife } \\
\hline$w_{f}$ & \multicolumn{2}{|c|}{$1326.512 *(627.02)$} & & $1483.377 *(651.892)$ \\
\hline$w_{m}$ & \multicolumn{2}{|c|}{$429.872(286.28)$} & & $628.151 *(307.284)$ \\
\hline Non-labour income & \multicolumn{2}{|c|}{$0.370(0.232)$} & & $0.428 *(0.213)$ \\
\hline Disability of wives & \multicolumn{2}{|c|}{$-1275.71 *(534.06)$} & & $-1308.95^{*}(565.11)$ \\
\hline Collective rationality Chi square test & \multicolumn{2}{|c|}{$0.280[0.594]$} & & $0.122[0.741]$ \\
\hline
\end{tabular}

Time use on labour market and household domestic production are expressed in hours per day

Standard errors within brackets, $\mathrm{p}$-values within square brackets, ${ }^{*} \mathrm{p}<0.05$. ${ }^{* *} \mathrm{p}<0.01 .{ }^{* * *} \mathrm{p}<0.001{ }^{\dagger} \mathrm{p}<0.10$

the number of children is negatively correlated to husband's labour supply, indicating that women who earn more have a higher degree of bargaining power and they spend less time on childcare.

The partial derivatives in the Panel B of Table 5 represented the change in the non-labour market income share that each of the partners can claim, as a function of changes in the spouses' wages, the non-labour income and the distribution factor of disability. Also, we reported the results of the collective rationality test, which showed whether the collective model was preferred to the unitary model. In our case, we failed to reject the null hypothesis, and the collective model was preferred. We found that disabled wives reduced their share by $1275 \mathrm{ID}(\$ 1.08)$ and increases in the wife's wage led to an increase in her share by 1320 ID (\$1.1).

When we considered only the labour market time, the wife's sharing rule on non-labour income was nonsignificant. In the Columns (3) and (4) considering the housework time we observed the sharing rule of the non-labour income for wives became significant and a one ID increase raised the share by 0.43 . Wives can claim 1470 ID $(\$ 1.25)$ and 630 ID $(\$ 0.50)$ respectively with increases in their wage and the husbands' wage. Disabled wives in this case reduced even more their share of the full income by 1310 ID (\$1.11). The results showed that when the household domestic production or household chores were included in the total working supply equations the sharing rules became larger confirming the assumptions of the methodological framework. The sharing of disabled spouses was decreased even more, when we considered also the household domestic production, since they may have to spend time on rehabilitation activities, care, and resting.

Overall, we observed that the estimated coefficients of the disability status and spouses' education and age confirm the theory of the distribution factors. More specifically, we concluded that these factors strongly influenced both partners' labour supplies according to the interpretation of the distribution factor, and hence, the estimates support the hypothesis that there are factors that may influence the household decisions through their impact on the intra-household allocation process. Regarding the wage effect, we showed that both partners work more hours when their own wages increased and reduced their time use in the labour market when the spouse's wage increased. So far our findings are consistent 
with the results of earlier studies (Browning et al. 1994; Browning and Chiappori 1998; Bourguignon et al. 2009; Chiappori et al. 2002; Fortin and Lacroix 1997).

Next we present the labour supply equations for married couples, considering also when the wife does not participate in the labour market. As we mentioned in the methodology section, the wife's decision to participate in the labour market should be modelled using the reservation wages which is the minimum wage indicating the initial point that she will be willing to work (Cogan 1981). This hypothesis implies that the wife enjoys the same level of utility whether she participates in the labour market or not and the husband must receive the same share of income whatever the wife's decision was. The distribution of the labour market and domestic labour supply hours may change even when his hours of total work remained unaffected. The shares of the non-labour income ranged between 0.32 and 0.37 , while in the case of the women who work the shares reached at 0.43. A similar situation was observed for increases at both spouses' wages, where the share for women was lower. About our main distribution factor of interest that is the disabled women, we illustrated in Table 6, that the share is - 1720 ID (\$1.5) while the respective share in the two-earner couples was - 1275 ID (\$1.08).

Overall, the main concluding remarks so far are the following: First, the labour supply, household domestic production, and the total labour supply of both spouses depend on the spouses' wages. Second, the distribution factor-disability-employed in this study is significant and has an impact on the spouses' labour supply choices, suggesting that the collective household model is the appropriate approach for the two-earner couples in Iraq. This further holds when we include also the case of female non-participation in the labour market. Third, considering additionally the domestic production as a non-pure leisure time and as a production of marketable goods and services that are produced in the household, the share or the bargaining power of female is higher in terms of her wage and non-labour income.

The disability status and labour supply in Iraq presents similar characteristics with other countries in the Middle East and North Africa (MENA). It is observed that due to high cost of treatment and care, disabilities add to social costs and have a negative effect not only on labour supply, but also on labour productivity. Most of these costs could be avoided

Table 6 GMM estimates of the labour supply and domestic production Eqs. (5) and (6) with female non-participation

\begin{tabular}{|c|c|c|c|c|}
\hline \multirow[t]{2}{*}{ Variables } & \multicolumn{2}{|l|}{ Labour supply } & \multicolumn{2}{|c|}{ Labour supply and domestic production } \\
\hline & Husband & Wife & Husband & Wife \\
\hline \multicolumn{5}{|l|}{ Panel A: GMM estimates } \\
\hline Log of female rate $\ln w_{f}$ & $-0.572^{\dagger}(0.328)$ & $1.398 *(0.555)$ & $-0.492 *(0.232)$ & $0.916 *(0.442)$ \\
\hline Log of male wage $\ln w_{m}$ & $3.351 *(1.571)$ & $-3.509 *(1.751)$ & $2.729^{\dagger}(1.402)$ & $-3.114 *(1.544)$ \\
\hline Interaction of spouse' wages $\ln w_{m} \times \ln w_{f}$ & $0.426 *(0.209)$ & $0.496 *(0.242)$ & $0.436 *(0.193)$ & $0.502^{\dagger}(0.274)$ \\
\hline Non-labour income $(y)$ & $-0.046^{*}(0.022)$ & $-0.028 *(0.013)$ & $-0.044 *(0.020)$ & $-0.028 *(0.012)$ \\
\hline Age & $0.087 *(0.042)$ & $0.104 *(0.046)$ & $0.072^{\dagger}(0.037)$ & $0.117 * *(0.041)$ \\
\hline Education & $0.162(0.124)$ & $0.143^{\dagger}(0.078)$ & $0.161^{\dagger}(0.084)$ & $0.165(0.122)$ \\
\hline Number of children $0-5$ years old & $-1.626(1.548)$ & $-2.126 *(1.012)$ & $-0.395^{\dagger}(0.206)$ & $-1.268 *(0.524)$ \\
\hline Number of children 6-15 years old & $0.885(1.283)$ & $-0.985^{\dagger}(0.502)$ & $1.804(1.337)$ & $-0.573^{\dagger}(0.293)$ \\
\hline Disabled female & $1.593^{\dagger}(0.902)$ & $-2.832 *(1.227)$ & $3.134 * * *(0.393)$ & $-2.986 *(1.458)$ \\
\hline Urban area & $0.893(1.102)$ & $1.317(0.977)$ & $-0.2003^{\dagger}(0.1105)$ & $-0.290(0.208)$ \\
\hline Disabled female $\times$ female wage & $1.520(1.169)$ & $0.411 *(0.189)$ & $1.342(1.009)$ & $0.627 *(0.315)$ \\
\hline Non-labour income $(y) \times$ female wage & $-0.027(0.022)$ & $-0.034(0.023)$ & $-0.033 *(0.019)$ & $-0.029(0.025)$ \\
\hline No. observations & 33,242 & 33,242 & 33,242 & 33,242 \\
\hline \multirow[t]{2}{*}{ Hansen's J test statistic } & $9.194[0.418]$ & & $12.821[0.207]$ & \\
\hline & \multicolumn{2}{|c|}{$\partial \varphi / \partial \mathrm{x}$} & \multicolumn{2}{|c|}{$\partial \varphi / \partial \mathrm{x}$} \\
\hline \multicolumn{5}{|l|}{ Panel B: sharing rules for wife } \\
\hline$w_{f}$ & \multicolumn{2}{|c|}{$1007,179^{\dagger}(568.90)$} & \multicolumn{2}{|c|}{$1204.24 *(563.18)$} \\
\hline$w_{m}$ & \multicolumn{2}{|c|}{$530.739(514.67)$} & \multicolumn{2}{|c|}{$495.153^{\dagger}(255.98)$} \\
\hline Non-labour income & \multicolumn{2}{|c|}{$0.320^{\dagger}(0.168)$} & \multicolumn{2}{|c|}{$0.371 *(0.159)$} \\
\hline Disability of wives & \multicolumn{2}{|c|}{$-1720.42^{\dagger}(912.85)$} & \multicolumn{2}{|c|}{$-1.975 .25^{*}(853.613)$} \\
\hline Collective rationality Chi square test & \multicolumn{2}{|c|}{$1.45[0.117]$} & \multicolumn{2}{|c|}{$0.05[0.7971]$} \\
\hline
\end{tabular}

Time use on labour market and household domestic production are expressed in hours per day

Standard errors within brackets, $\mathrm{p}$-values within square brackets, ${ }^{*} \mathrm{p}<0.05,{ }^{*} * \mathrm{p}<0.001,{ }^{\dagger} \mathrm{p}<0.10$ 
through mitigation mechanisms and appropriate prevention. Much work remains to be done to strengthen public policies and programs to prevent disabilities by reducing their occurrence and their long-term impact through early identification of the risk factors and introduction of preventive measures. Also many policies and mechanisms in MENA countries are missing to integrate people in the labour markets (Hakim and Jaganjac 2005; United Nations 2016).

However, there are major drawbacks in the empirical analysis of the study. As we mentioned earlier, the main limitation is that the model set up and its empirical strategy relies on cross-sectional data ignoring the dynamic effects of spouses' participation in the labour market and domestic production, wage, non-labour income, and health status. Therefore, a panel data set or repeated cross-sectional data could be very useful to estimate these relationships within a dynamic framework providing more precise and insightful estimates.

Another major limitation is the small sample of women participating in the labour market, which is roughly only $2.7 \%$. Even though the female participation in Iraq is very low, estimates still are likely to not be precise and robust. This can be overcome by including panel structure in the analysis, as we mentioned, and taking large-scale surveys.

Also, an important drawback of the analysis is the disability severity which information is unavailable in the dataset we used. In particular, the disability registration does not imply that the severity is homogenous among the households. Therefore, alternative health and disability measures can be used, including the EQ-5D, which is a generic instrument that assesses the health related quality of life (HRQoL) in terms of mobility, self-care, usual activities, pain/discomfort, and anxiety/depression (Brooks 1996; EuroQol Group 1990; Rabin and de Charro 2001). This measure provides more information on the degree of the disability severity and its impact on household expenditures, disability costs, and labour supply.

Furthermore, the absence of panel data limits the analysis of investigating the disability shocks or the transition from healthy to disabled states and their impact on labour participation. Another point that this research has not examined is that children are modelled as household attributes and not as separate economic agents with individual utility functions. Even though children may not express their own preferences when they are young, it is reasonable to assume that the parents allocate resources to maximise their children's utility, especially when they are ill or disabled.

\section{Conclusions}

The study showed the definitions of the intra-household resource allocation considering the female non-participation in the labour market and the disability status. The setting and estimation of this model can be useful for designing and implementing efficient welfare policies related to the reduction of inequality and child poverty and the incentives of female labour supply. This is feasible if the intra-household resource allocation is known in terms of income and time use.

The findings support the assumption that changes in the non-labour income and distribution factors influence the labour supply choices and the spouses' wages are significant factors of bargaining power. When wife non-participation in the labour market is considered, the results show that she can claim 0.37 of the non-labour income and increases at 0.43 when we included the household domestic production. The disability has a larger effect compared to the two-earner couples and her share is reduced, while the loss becomes even larger when the household domestic production is included. This may be explained by the fact that a sample of the wives that do not participate can be severely disabled and, thus, better information and measures about the disability status should be taken into consideration.

Therefore, the conclusion is that disabled women are placed in a more vulnerable position compared to the healthier women and those who are able to participate in the labour market. Moreover, the non-disabled people may have access to jobs of better quality, be more productive, and have higher potential earnings. Overall, disability is an important and crucial factor that determines and affects both labour market and household domestic production.

However, there are still major practical issues about the disability rights and policies in Iraq. The Iraqi context explored in this study is a topic that has to receive a closer view, along with other countries in the region, as women and girls are imprisoned by disability and society norms and traditions. Disabled women are less likely to be employed and more likely to participate less hours in the labour market. Furthermore, the employment opportunities for persons with disabilities, and especially women, tend to be limited to simple projects, characterised as very few and mostly humiliating (United Nations 2016). The situation also appears particularly difficult for the disabled women, but also for children living in rural areas having very limited access to educational opportunities, health centres, and specialized services. The government should promote the empowerment of women with disabilities enabling them to participate in all spheres of life on an equal basis with others, and especially an active participation in the labour market.

Acknowledgements The authors would like to thank the Editor Professor Elizabeth M. Dolan and three anonymous reviewers and are grateful for their valuable inputs, suggestions and constructive comments that greatly contributed to the improvement of the quality of this paper. The authors are responsible for any remaining errors or omissions. 
Funding The study is funded by the Economic Research Forum (ERF) and the grant received under the "Arab Spring Development Initiative (ASDI)" programme call on "The Political Economy of Contemporary Arab Societies".

\section{Compliance with Ethical Standards}

Conflict of interest The authors declare that they have no conflict of interest.

Ethical Approval This article does not contain any studies with human participants performed by any of the authors.

Open Access This article is distributed under the terms of the Creative Commons Attribution 4.0 International License (http://creativeco mmons.org/licenses/by/4.0/), which permits unrestricted use, distribution, and reproduction in any medium, provided you give appropriate credit to the original author(s) and the source, provide a link to the Creative Commons license, and indicate if changes were made.

\section{References}

Apps, P., \& Rees, R. (1988). Taxation and the household. Journal of Public Economics, 35(3), 355-369. https://doi.org/10.1016/00472727(88)90037-0.

Arias, C., Atella, V., Castagnini, R., \& Perali, F. (2004). Estimation of the sharing rule between adults and children and related equivalence scales within a collective consumption framework. In C. Dagum \& G. Ferrari (Eds.), Household behaviour, equivalence scales, welfare and poverty. Contributions to statistics (pp. 129161). Heidelberg: Physica-Verlag.

Aronsson, T., Daunfeldt, S. V., \& Wikström, M. (2001). Estimating intra-household allocation in a collective model with household production. Journal of Population Economics, 14(4), 569-584. https://doi.org/10.1007/s001480100088.

Attanasio, O., \& Lechene, V. (2002). Tests of income pooling in household decisions. Review of Economic Dynamics, 5(4), 720-748. https://doi.org/10.1006/redy.2002.0191.

Becker, G. S. (1981). Treatise on the family. Cambridge: Harvard University Press.

Bianchi, S. M., Lesnard, L., Nazio, T., \& Raley, S. (2014). Gender and time allocation of cohabiting and married women and men in France, Italy, and the United States. Demographic Research, 31(8), 183-216. https://doi.org/10.4054/DemRes.2014.31.8.

Blundell, R., Chiappori, P. A., Magnac, T., \& Meghir, C. (2007). Collective labor supply: Heterogeneity and non-participation. Review of Economic Studies, 74(2), 417-445. https://doi.org/10.1111/ j.1467-937X.2007.00440.x.

Blundell, R., Chiappori, P. A., \& Meghir, C. (2005). Collective labour supply with children. Journal of Political Economy, 113(6), 12771306. https://doi.org/10.1086/491589.

Blundell, R., Duncan, A., \& Meghir, C. (1998). Estimating labor supply responses using tax reforms. Econometrica, 66(4), 827-861. https ://doi.org/10.2307/2999575.

Bourguignon, F., Browning, M., \& Chiappori, P. A. (2009). Efficient intra-household allocations and distribution factors: Implications and identification. Review of Economic Studies, 76(2), 503-528. https://doi.org/10.1111/j.1467-937X.2008.00525.x.

Bourguignon, F., Browning, M., Chiappori, P. A., \& Lechene, V. (1993). Intrahousehold allocation of consumption: A model and some evidence from French data. Annales d'Économie et de Statistique, 29, 137-156. https://doi.org/10.2307/20075899.

Brewer, M., Cattan, S., Crawford, C., \& Rabe, B. (2016). Free childcare and parents' labour supply: is more better? Institute for Fiscal Studies, IFS No. WP, W16/22, London. https://doi.org/10.13140 /RG.2.2.30779.41762.

Brooks, R. (1996). Euroqol: The current state of play. Health Policy, 37(1), 53-72. https://doi.org/10.1016/0168-8510(96)00822-6.

Browning, M., Bourguignon, F., Chiappori, P. A., \& Lechene, V. (1994). Incomes and outcomes: A structural model and some evidence from French data. Journal of Political Economy, 102(6), 1067-1096. https://doi.org/10.1086/261964.

Browning, M., \& Chiappori, P.-A. (1998). Efficient intra-household allocations: A general characterization and empirical tests. Econometrica, 66(6), 1241-1278. https://doi.org/10.2307/29996 16.

Browning, M., Chiappori, P.-A., \& Lechene, V. (2006). Collective and unitary models: A clarification. Review of Economics of the Household, 4(1), 5-14. https://doi.org/10.1007/s1115 0-005-6694-2.

Burchardt, T., \& Zaidi, A. (2008). Disabled children, poverty and extra costs. In J. Strelitz \& R. Lister (Eds.), Why money matters: Family income, poverty and children's lives (pp. 26-33). London: Save the Children Fund.

Butikofer, A., Lewbel, A., \& Seitz, S. (2011). Health and retirement effects in a collective consumption model of older households (767). Boston: Center for Retirement Research Boston College, No. WP.

Carlin, P. S., \& Flood, E. (1997). Do children affect the labor supply of Swedish men? Time diary versus survey data. Labour Economics, 4(2), 167-183. https://doi.org/10.1016/S0927-5371(96)00011-5.

Chavas, J.-P., Menon, N., Pagam, E., \& Perali, F. (2018). Collective household welfare and intra-household inequality. Theoretical Economics, 13(2), 667-696. https://doi.org/10.3982/TE2459.

Chiappori, P. A. (1988). Rational household labor supply. Econometrica, 56(1), 63-89. https://doi.org/10.2307/1911842.

Chiappori, P. A. (1992). Collective Labor supply and welfare. Journal of Political Economy, 100(3), 437-467. https://doi. org/10.1086/261825.

Chiappori, P. A., \& Ekeland, I. (2009). The microeconomics of efficient group behavior: Identification. Econometrica, 77(3), 763-799. https://doi.org/10.3982/ECTA5929.

Chiappori, P. A., Fortin, B., \& Lacroix, G. (2002). Marriage market, divorce legislation and household labor supply. Journal of Political Economy, 110(1), 37-72. https://doi.org/10.1086/324385.

Cogan, J. F. (1981). Fixed costs and labor supply. Econometrica, 49(4), 945-963. https://doi.org/10.2307/1912512.

Cooke, L. P., \& Janeen, B. (2010). Families in International context: Comparing institutional effects across western societies. Journal of Marriage and Family, 72(3), 516-536. https://doi.org/10.111 1/j.1741-3737.2010.00716.x.

Crespo, L. (2009). Estimation and testing of household labour supply models: Evidence from Spain. Investigaciones Económicas, 33(2), 303-335.

Cullinan, J., \& Lyons, S. (2015). The private economic costs of adult disability. In J. Cullinan, S. Lyons \& B. Nolan (Eds.), The economics of disability: Insights from Irish research (pp. 58-73). Manchester: Manchester University Press.

Davidson, R., \& Mackinnon, J. G. (1993). Estimation and inference in econometrics. Oxford: Oxford University Press.

Devereux, P. J. (2004). Changes in relative wages and family labor supply. The Journal of Human Resources, 39(3), 696-722. https ://doi.org/10.3368/jhr.XXXIX.3.698.

Donni, O., \& Moreau, N. (2007). Collective labor supply: A singleequation model and some evidence from French data. The Journal 
of Human Resources, 42(1), 214-246. https://doi.org/10.3368/jhr. XLII.1.214.

EuroQol Group. (1990). Euroqol—a new facility for the measurement of health-related quality of life. Health Policy, 16(3), 199-203. http://www.jstor.org/stable/40057303.

Fortin, B., \& Lacroix, G. (1997). A test of the unitary and collective models of household labour supply. The Economic Journal, 107(443), 933-955. https://doi.org/10.1111/j.1468-0297.1997. tb00001.x.

Gallipoli, G., \& Turner, L. (2009). Household responses to individual shocks: disability and labor supply university of British Columbia. 04_09: Rimini Centre for Economic Analysis (RCEA), No. WP.

Giovanis, E., \& Ozdamar, O. (2018). Empirical application of collective household labour supply model in Iraq. Economic Research Forum (ERF), No. WP, 1180, April, Cairo, Egypt.

Goldschmidt-Clermont, L., \& Pagnossin-Aligisakis, E. (1995). Measures of unrecorded economic activities in fourteen countries. Background Papers for the Human Development Report, Oxford: UNDP.

Hakim, G., \& Jaganjac, N. (2005). A note on disability issues in the Middle East and north Africa. Human Development Department. Retrieved from World Bank database [37275].

Heckman, J. J. (1979). Sample selection bias as a specification error. Econometrica, 47(1), 153-161. https://doi.org/10.2307/1912352.

Hendy, R., \& Sofer, C. (2010). A Collective Model of Female Labor Supply: Do Distribution Factors Matter in the Egyptian Case? Documents de travail du Centre d'Economie de la Sorbonne, No. WP., 2010.35 .

Hiatt, A. R., \& Godwin, D. D. (1990). Use of time and preferences for time allocation among urban, employed, married women. Lifestyles: Family and Economic Issues, 11(2), 161-181. https://doi. org/10.1007/BF00987079.

Hilton, J. M. (1990). Differences in allocation of family time spent on household tasks among single-parent, one-earner, and two-earner families. Lifestyles: Family and Economic Issues, 11(3), 283-298. https://doi.org/10.1007/BF00987004.

Jones, M. K., Latreille, P. L., \& Sloane, P. J. (2006). Disability, gender, and the British labour market. Oxford Economic Papers, 58(3), 407-449. https://doi.org/10.1093/oep/gpl004.

Kooreman, P., \& Kapteyn, A. (1986). Estimation of rationed and unrationed household labour supply functions using flexible functional forms. The Economic Journal, 96(382), 398-412. https://www. jstor.org/stable/2233123.

Lundberg, S. (2002). The effects of sons and daughters on men's labor supply and wages. The Review of Economics and Statistics, 84(2), 251-268. https://doi.org/10.1162/003465302317411514.

Lundberg, S., Pollak, R. A., \& Wales, T. (1997). Do husbands and wives pool their resources? Evidence from the uk child benefit. The Journal of Human Resources, 32(3), 463-480. https://doi. org/10.2307/146179.

Makkonen, T. (2002). Multiple, compound and intersectional discrimination: Bringing the experience of the most marginalized to the fore. Institute for Human Rights, Abo Akademi University: Turku.

OECD. (2009). Sickness, disability and work: keeping on track in the economic downturn. Paris: Organisation for Economic Cooperation and Development. Retrieved from OECD database [42699911].

Ozdamar, O., \& Giovanis, E. (2016). The link between health condition costs and standard of living: a structural equation modelling. Economic Research Forum (ERF), No. WP., 1060, Cairo, Egypt. https://doi.org/10.13140/RG.2.2.36571.16160.

Parodi, G., \& Sciulli, D. (2008). Disability in Italian households: Income, poverty and labour market participation. Applied Economics, 40(20), 2615-2630. https://doi.org/10.1080/0003684060 0970211.
Pitt, M. M., \& Rosenzweig, M. R. (1990). Estimating the intra-household incidence of illness: Child health and gender inequality in the allocation of time. International Economic Review, 31(4), 969-989. https://www.jstor.org/stable/2527025.

Rabin, R., \& de Charro, F. (2001). Eq-5d: a measure of health status from the euroqol group. Annals of Medicine, 33(5), 337-343. https ://doi.org/10.3109/07853890109002087@.

Rapoport, B., Sofer, C., \& Sola, A. (2011). Household production in a collective model: Some new results. Journal of Population Economics, 24(1), 23-45. https://doi.org/10.1007/s00148-010-0308-x.

Rioux, M., \& Pinto, P. C. (2014). Are we moving forward? Regional study on the rights of women with disabilities in the Middle East. Retrieved from https://haqqi.info.

Roushdy, R. (2004). Intra household resource allocation in Egypt: Does women's empowerment lead to greater investments in children? (0401). Cairo, Egypt: Economic Research Forum (ERF), No. WP.

Samuelson, P. (1956). Social indifference curves. Quarterly Journal of Economics, 70(1), 1-22. https://doi.org/10.2307/1884510.

Sayer, L. C., Bianchi, S. M., \& Robinson, J. P. (2004). Are parents investing less in children? Trends in mothers' and fathers' time with children. American Journal of Sociology, 110, 1-43. https ://doi.org/10.1086/386270.

Tibble, M. (2005). Review of the existing research on the extra costs of disability. No. WP, 21. London: Department for Work and Pensions.

UNICEF (2010). The Cost and benefits of education in Iraq: An analysis of the education sector and strategies to maximize the benefits of education. Government of Iraq, UN Children's Fund. Retrieved from http://reliefweb.int/report/iraq/girls-educationi raq-2010.

United Nations (2007). Convention on the rights of persons with disabilities and optional protocol, p. 4. http://www.un.org/disab ilities/documents/convention/convoptprot-e.pdf.

United Nations (2015). The world's women 2015: Trends and statistics. Retrieved from https://unstats.un.org/unsd/gender/world swomen.html.

United Nations (2016) Report on the rights of persons with disabilities in Iraq. United Nations Assistance Mission for Iraq (UNAMI). Retrieved from http://www.uniraq.org/.

USAID (2014). Iraq access to justice program, values of access to justice and persons with disabilities in Iraq. Washington, DC: United States Agency for International Development.

Uunk, W., Kalmijn, M., \& Muffels, R. (2005). The impact of young children on women's labour supply:A reassessment of institutional effects in Europe. Acta Sociologica, 48(1), 41-62. https ://doi.org/10.1177/0001699305050986.

Vermeulen, F. (2002). Collective household models: Principles and main results. Journal of Economic Surveys, 16(4), 533-564. https://doi.org/10.1111/1467-6419.00177.

Warner, D. F., \& Brown, T. H. (2011). Understanding how race/ ethnicity and gender define age-trajectories of disability: An intersectionality approach. Social Science and Medicine, 72(8), 1236-1248. https://doi.org/10.1016/j.socscimed.2011.02.034.

Wilfred, U., Kalmijn, M., \& Muffels, R. (2005). The impact of young children on women's labor supply. A reassessment of institutional effects in Europe. Acta Sociologica, 48(1), 41-62. https ://doi.org/10.1177/0001699305050986.

Zaidi, A., \& Burchardt, T. (2005). Comparing incomes when needs differ: equivalization for the extra costs of disability in the UK. Review of Income and Wealth, 51(1), 89-114. https://doi.org/1 0.1111/j.1475-4991.2005.00146.x. 
Eleftherios Giovanis studied economics at the University of Thessaly. He completed the M.Sc. in applied economics and finance and a second M.Sc. in quality assurance He worked as statistician and econometrician analyst is marketing research companies. In April of 2015 he completed his Ph.D. in economics at Royal Holloway University of London. Since then he worked as post-doc and was awarded with various the Marie Sklodowska-Curie Research Individual Fellowship at University of Verona. Also, he worked in various funded projects. Currently, he is Senior Lecturer at Manchester Metropolitan University at the Department of Economics, Policy and International Business.

Oznur Ozdamar is an Assistant Professor in the Department of Econometrics, Faculty of Economics at Adnan Menderes University. She was Post-Doctoral Research Fellow at Bologna University/Department of
Economics working on a project related with the impact of air pollution on health. She studied economics and received her Ph.D. from IMT Institute for Advanced Studies in Italy. During her Ph.D., she was a Research Fellow at Northwestern University in USA where she wrote a significant part of her dissertation. Her research interests are health economics, environmental economics, economics of gender and social welfare policies. Over the last years she worked as Principal Investigator and Research Collaborator in various projects funded by various institutions. 